\title{
Síndrome de hiperparatiroidismo por tumor maxilar
}

\author{
Hyperparathyroidism-jaw tumour syndrome
}

\author{
L. Barroso', J. Pedro Marcelino², L. Jiménez Romero', I. Amado², A. Ferreira², C. Alberto Ribeiro³
}

Resumen: El hiperparatiroidismo tiene con frecuencia manifestaciones óseas, de predomínio facial en algunos pacientes.

Los autores describen las manifestaciones en una família de la región central de Portugal, como punto de partida para una revisión de los conocimientos sobre esta entidade clínica todavía poco divulgada y que puede tener como primera manifestación la presentación de tumores faciales.

Palabras clave: Hiperparatiroidismo; Tumores faciales; Fibromas osificantes; Síndrome HPT-TM.

Recibido: 24.11 .05

Aceptado: 16.06 .08
Abstract: Hyperparathyroidism frequently has bone effects. In one subset of patients, these effects involve mainly facial bones (hyperparathyroidism-jaw tumour syndrome).

The authors describe an affected family from central Portugal and discuss the features of this still poorly known disease, which can present initially as a facial tumour.

Key words: Hyperparathyroidism; Jaw tumours; Ossifying fibromas; HPT-JT syndrome.

1 Médico Residente

2 Cirujano Oral y Maxilofacial

3 Jefe de Servicio

Servicio de Cirugía Oral y Maxilofacial. Hospitais da Universidade de Coimbra (HUC),

Portugal

\section{Correspondencia:}

Leonor Barroso

Serviço de Cirurgia Maxilo-Facial

Hospitais da Universidade de Coimbra

3000-075 Coimbra, Portugal

Email: leonorbarroso@netcabo.pt 


\section{Introducción}

El hiperparatiroidismo primario, con una incidencia que alcanza 1:1000, es la tercera de entre las enfermedades endocrinas más frecuentes, tras la diabetes mellitus y el hipertiroidismo. ${ }^{1}$ En su mayor parte, los casos son esporádicos y solamente un $10 \%$ son familiares. ${ }^{2}$ El hiperparatiroidismo primario incluye principalmente los síndromes de neoplasia endocrina múltiple de tipo 1 ó 2 (MEN, multiple endocrine neoplasm) y el hiperparatiroidismo asociado a tumor maxilar-el síndrome del hiperparatiroidismo por tumor maxilar (HPT-TM). Se han publicado algunos casos de hiperparatiroidismo familiar aislado pero la mayoría de éstos parecen ser casos menores de los otros síndromes, con un fenotipo incompleto, que probablemente corresponden a mutaciones ligeramente diferentes del mismo gen.3,4

\section{Material y método}

En nuestro hospital, se han evaluado $y$ tratado a varias personas que comparten una línea de parentesco común (Fig. 1) y padecen HPT-TM. Esta línea de parentesco ha sido descrita en publicaciones endocrinológicas, ${ }^{5}$ pero la presentamos aquí a la comunidad de la cirugía oral y maxilofacial para subrayar las manifestaciones faciales implicadas.

\section{Caso 1}

En 1993, un varón de 73 años ingresó en el servicio de medicina interna con el diagnóstico provisional de metástasis ósea de tumor primario desconocido. Había perdido $15 \mathrm{~kg}$ en 18 meses y manifestaba anorexia, estreñimiento, dolor del muslo izquierdo y elevación de las concentraciones sanguíneas de calcio, bilirrubina y las fosfatasas ácida y alcalina. La gammagrafía ósea (Fig. 2) demostró zonas múltiples de mayor captación y osteoartropatía hipertrófica, sugiriendo enfermedad metastásica.

La historia personal del paciente no ofrecía nada reseñable, salvo haber sido intervenido por un tumor maxilar a la edad de 18 años (1938). No estaba disponible el diagnóstico histológico de este tumor.

Durante el ingreso, se encontraron niveles elevados de parathormona urinaria y de calcio sanguíneo. La ecografía cervical demostró aumento del tamaño de la glándula paratiroidea inferior derecha.

El paciente se sometió a hemitiroidectomía derecha con excisión de la paratiroides agrandada y la glándula ipsilateral; se normalizó

\section{Introduction}

Primary hyperparathyroidism, with an incidence reaching 1:1000, is the third most frequent endocrine disease after diabetes mellitus and hyperthyroidism. ${ }^{7}$ Most cases are sporadic and only about 10\% are familial. ${ }^{2}$ Primary hyperparathyroidism includes mainly multiple endocrine neoplasm (MEN) syndromes type 1 or 2, as well as hyperparathyroidism associated with jaw tumours - hyperparathyroidism-jaw tumour syndrome (HPT-JT). A few cases of isolated familial hyperparathyroidism have been published but, for the most part, they seem to be minor cases of the other syndromes, with incomplete phenotypes, probably corresponding to slightly different mutations of the same gene. ${ }^{3,4}$

\section{Material and method}

In our hospital, several members of a kindred (Fig. 1) with HPT-JT have been evaluated and treated. This kindred has been described in endocrinological journals, 5 but we are presenting it to the oral and maxillofacial surgery community to highlight the facial manifestations.

\section{Case 1}

In 1993, a 73-year-old man was admitted to one of our Internal Medicine ward with the provisional diagnosis of bone metastasis of an unknown primary tumour. He had lost $15 \mathrm{~kg}$ in 18 months and had anorexia, constipation, pain over the left thigh and elevated blood levels of calcium, bilirubin, and acid and alkaline phosphatase. The bone scan (Fig. 2) showed multiple areas of elevated uptake and hypertrophic osteoarthropathy, suggesting metastatic disease.

The patient's personal history was irrelevant, apart from surgery on a maxillary tumour at the age of 18 years (1938). The histological diagnosis of this tumour was not available.

During admission, elevated levels of urinary calcium and blood parathormone were found. Cervical ultrasonography showed an enlarged right inferior parathyroid gland. 
inmediatamente la calcemia. El estudio histopatológico demostró carcinoma infiltrante de la paratiroides inferior e hiperplasia de la paratiroides superior.

Dos años más tarde, se presentó de nuevo dolor óseo y estreñimiento con niveles elevados de calcio y de parathormona en sangre. En una nueva intervención, se hizo una hemitiroidectomía, paratiroidectomía izquierda y timectomía. Se normalizó la calcemia pero el paciente murió dos años más tarde por causas no relacionadas.

\section{Caso 2}

En 1987, un paciente de 43 años, el hijo mayor del paciente $\mathrm{n}^{\circ} 1$, ingresó en nuestro servicio de cirugía oral y maxilofacial con un gran tumor de la mandíbula izquierda (Fig. 3).

El tumor se había presentado 11 años antes, cuando el paciente vivía en otro lugar del país, y fue diagnosticado en el hospital local como un fibroma osificante. Se detectaron al mismo tiempo niveles altos en sangre de calcio y de parathormona. Se le resecó un adenoma paratiroideo.

Desde entonces, el tumor mandibular seguía creciendo y el paciente fue tratado varias veces con radioterapia y curetaje.

Cuando fue visto por primera vez en nuestro servicio, el paciente tenía un tumor voluminoso de la mandíbula izquierda con zonas de osteorradionecrosis e infección, además de dos masas más pequeñas en la maxila izquierda y la mandíbula derecha (Figs. 4 y 5). Evidenciaba además ceguera izquierda dolorosa producida por la radioterapia e insuficiencia renal incipiente.

Se realizó una enucleación del ojo izquierdo y hemimandibulectomía izquierda; no se hizo la reconstrucción debido a la presencia de infección local. El tumor resecado (13×18 $\mathrm{cm}$ ) era un fibroma osificante (Fig. 6).

Cinco años más tarde, se realizó hemimandibulectomía derecha con reconstrucción utilizando 2 injertos de costilla (Fig. 7); el diagnóstico histopatológico del tumor derecho fue el mismo. El paciente murió 3 años más tarde por las complicaciones del fallo renal, a pesar de tratarse con hemodiálisis desde 1990.

\section{Caso 3}

A la edad de 40 años (1987), este paciente se quejó de dolor de la mano derecha y del tercio medio de la pantorrilla izquierda. En

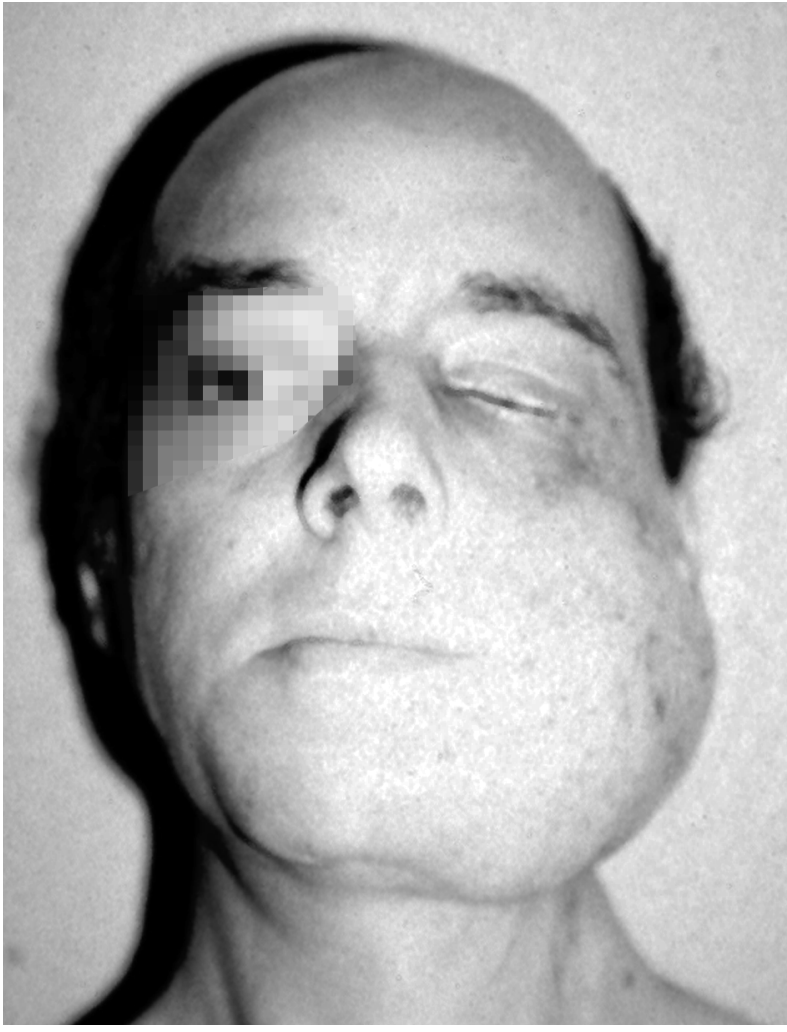

Figura 3. El paciente $n^{\circ} 2$, con un tumor voluminoso de la mandíbula izquierda.

Figure 3. Patient 2, with a voluminous left mandibular tumour.

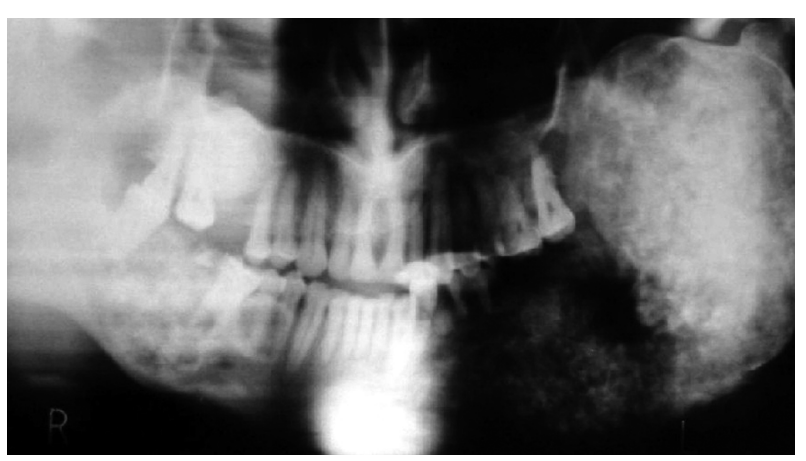

Figura 4. Ortopantomografía del paciente $\mathrm{n}^{\circ} 2$

Figure 4. Orthopantomography of patient 2.
The patient underwent right hemithyroidectomy, along with extirpation of the enlarged parathyroid and the other ipsilateral gland; blood calcium levels normalized immediately. Histopathological examination demonstrated an infiltrating carcinoma of the lower parathyroid and hyperplasia of the upper parathyroid.

Two years later, the bone pain and constipation reappeared, along with elevated blood calcium and parathormone levels. He had surgery again, undergoing left hemithyroidectomy, parathyroidectomy and thymectomy. The blood calcium normalized and the patient died two years later from unrelated causes.

\section{Case 2}

In 1987, a 43-year-old male patient, the older son of patient 1, was admitted to our Oral and Maxillofacial Surgery department with a very large tumour on the left mandible (Fig. 3).

This mass had appeared 11 years earlier, when he lived in another part of the country, and was diagnosed in the local hospital as an ossifying fibroma. Elevated blood calcium and parathormone levels were detected at the same time and he underwent resection of a parathyroid adenoma.

Meanwhile, the mandibular mass kept on growing and the patient submitted to curettage and radiation therapy several times.

When first seen in our department, the patient had a voluminous mass on the left mandible with areas of osteoradionecrosis and infection, and two smaller masses on the left maxilla and right mandible (Figs. 4 and 5). At the same time, he had painful left amaurosis caused by radiation therapy and initial renal failure.

He had left eye enucleation and left hemimandibulectomy; reconstruction was not performed because of the local 
la exploración realizada en el servicio de ortopedia de nuestro hospital, se encontraron lesiones quísticas en estas localizaciones y en una costilla y en la rama mandibular derecha (Fig. 8).

El paciente conocía la existencia de su lesión mandibular desde la edad de 23 años, cuando una biopsia confirmó su benignidad. Desde entonces, apenas había crecido y él no había buscado tratamiento.

Tres años antes, sufrió una fractura patológica de la rótula, que fue tratada en otro hospital.

La lesión cística de la mano derecha se diagnosticó, por biopsia, como osteoclastoma. La presencia de lesiones múltiples se atribuyó a una displasia fibrosa poliostótica.

El año siguiente, el paciente sufrió una nueva fractura patológica del fémur izquierdo (Fig. 9) y varios episodios de hematuria. Durante la evaluación de la hematuria, se encontraron niveles sanguíneos elevados de calcio y de parathormona, además de quistes de la corteza renal.

En 1989, se le hizo una hemitiroidectomía y se resecó un adenoma de la paratiroides inferior derecha.

Desde entonces, han permanecido normales los niveles de calcio y parathormona en sangre y el tumor mandibular no ha aumentado. El paciente no desea realizar una resección de esta lesión.

\section{Caso 4}

Estudiamos a esta paciente, hija del paciente $n^{\circ} 2$, en nuestro servicio en 1995, a la edad de 21 años. Presentó un tumor bien delimitado del cuarto cuadrante (Fig. 10), que extendía hasta el reborde basilar y tenía aspecto quístico, pero con cierta trabeculación.

Debido a sus antecedentes familiares de hiperparatiroidismo y tumor maxilar, se le remitió al servicio de endocrinología para evaluación.

Se encontraron niveles elevados de calcio y parathormona en sangre y osteítis fibroquística en estado avanzado (Fig. 11). El adenoma paratiroideo fue resecado, seguido más adelante por hemimandibulectomía derecha segmentaria con reconstrucción utilizando un aloinjerto de cadá-
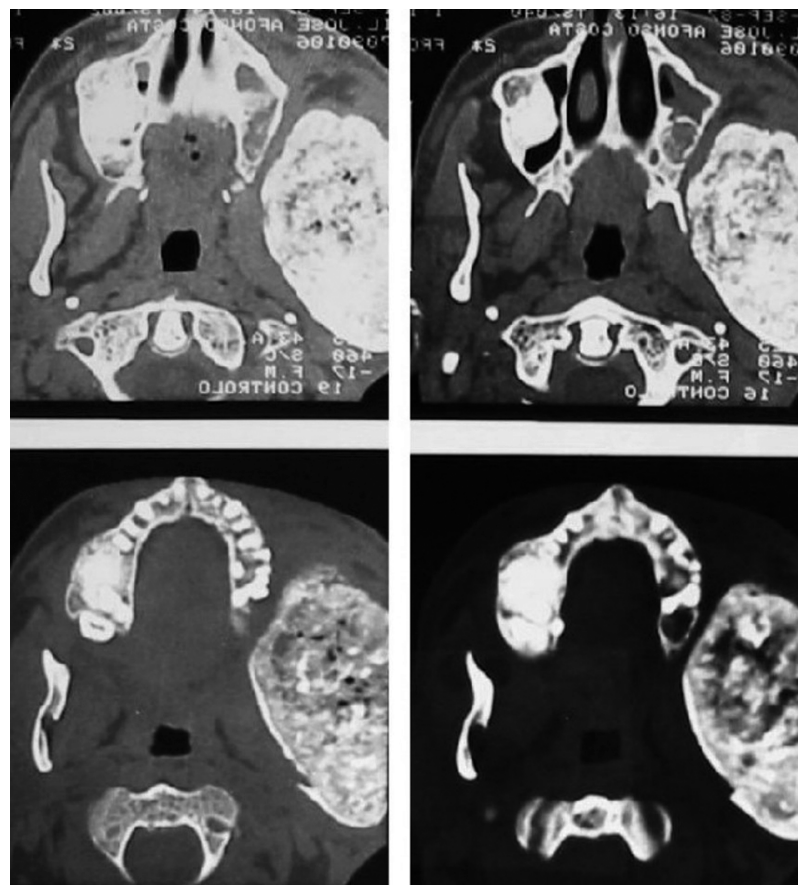

Figura 5. TC de las lesiones anteriores.

Figure 5. CT scan of the same lesions.

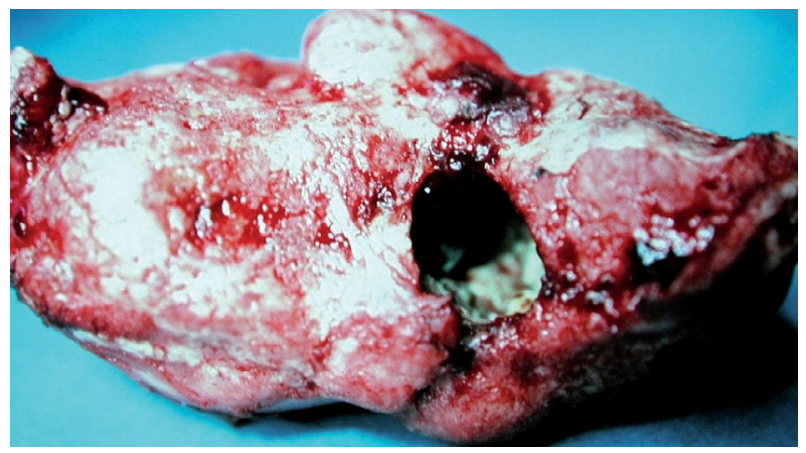

Figura 6. Hemimandíbula izquierda resecada.

Figure 6. Resected left hemimandible.

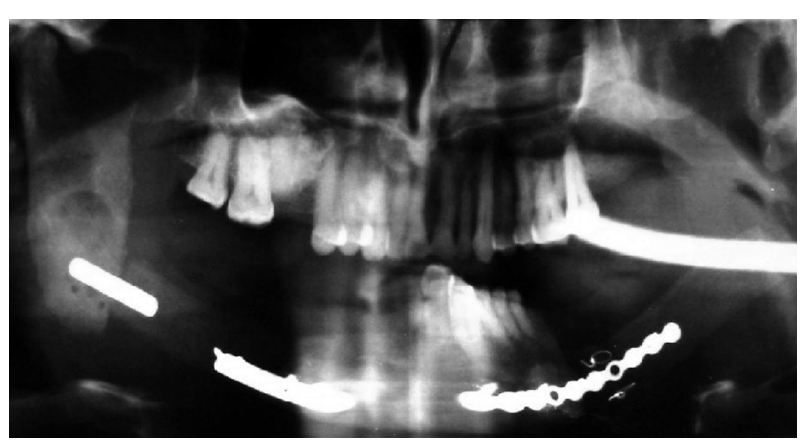

Figura 7. Reconstrucción con dos injertos de costilla. Figure 7. Reconstruction with two rib grafts. infection. The excised tumour $(13 \times 18 \mathrm{~cm})$ was an ossifying fibroma (Fig. 6).

Five years later, he underwent right hemimandibulectomy and reconstruction with 2 rib grafts (Fig. 7); the histopathological diagnosis of the right tumour was the same. The patient died 3 years later of renal failure complications, although he had been on haemodialysis since 1990.

\section{Case 3}

When he was 40 years old (1987), this patient suffered pain in his right hand and middle third of his left calf. He was examined in the Orthopaedics Department of our hospital and was found to have cystic lesions at these locations as well as in a rib and the right mandibular ramus (Fig. 8).

The patient had been aware of the mandibular lesion since he was 23 years old, when a biopsy showed that it was benign. As it had barely grown since then, he had not sought treatment.

Three years earlier, he had a pathologic fracture of the patella, which was treated in another hospital.

The cystic lesion on the right hand was diagnosed by biopsy as an osteoclastoma. Given the multiple lesions, he was believed to suffer from pluriostotic fibrous dysplasia. The following year, he had another pathological fracture of the left femur (Fig. 9) and several episodes of haematuria. During the evaluation of the haematuria, elevated blood calcium and parathormone levels and cortical renal cysts were found.

In 1989, he underwent right hemithyroidectomy and extirpation of a right lower parathyroid adenoma. 
ver (Fig. 12). El tumor era un fibroma osificante.

\section{Case 5}

Esta paciente, hija del paciente $\mathrm{n}^{\circ}$ 3, fue el objeto de un estudio de detección bioquímica y radiológica a la edad de 14 años. Se encontró hipocalcemia, hiperparatiroidismo, dos tumores maxilares (de los cuadrantes segundo y cuarto) y varios quistes renales

Se realizó paratiroidectomía derecha para tratar un adenoma paratiroideo. La calcemia permaneció normal durante un año, pero a partir de entonces empezó a aumentar. La paciente se intervino de nuevo (paratiroidectomía izquierda, tanto superior como inferior, y excisión de la mitad de la paratiroides superior derecha por un adenoma de la paratiroides superior izquierda). Las lesiones maxilares seguían creciendo y unos meses más tarde fueron resecados los dos fibromas osificantes (Fig. 13).

Posteriormente tuvo otro episodio de hiperparatiroidismo y fue intervenida para resecar el adenoma de la glándula restante. No hay ningún indicio de recidiva o de la presentación de tumores maxilares nuevos.

\section{Discusión}

En 1958, Jackson, ${ }^{6}$ describió a una familia con hiperparatiroidismo hereditario, en la mayoría de los casos acompañado de tumor maxilar, después de publicarse las observaciones de otros autores, en que definieron este síndrome, ${ }^{7}$ y lo diferenciaron de la neoplasia endocrina múltiple de tipos 1 y 2 (MEN-1 y MEN-2). ${ }^{8}$

EI HPT-TM es una enfermedad hereditaria autosómica dominante relacionada con el cromosoma 1 (1q25-q31), ${ }^{9}$ que origina tumores paratiroideos, fibroma osificante de la maxila, diversas lesiones renales (quistes, el tumor de Wilms, hamartoma, adenoma cortical, carcinoma de células papilares) y otros tumores (adenocarcinoma pancreático, tumor testicular, tumor de células de Hürthle del tiroides, pólipos adenomiomatosos del útero). ${ }^{10-12,18}$

Las manifestaciones más frecuentes (adenomas paratiroideos y fibromas osificantes) se presentan a edades más jóvenes que en los casos esporádicos, que son más frecuentes a la edad media, ${ }^{12}$ y después de la tercera década de la vida, ${ }^{13}$ respectivamente.

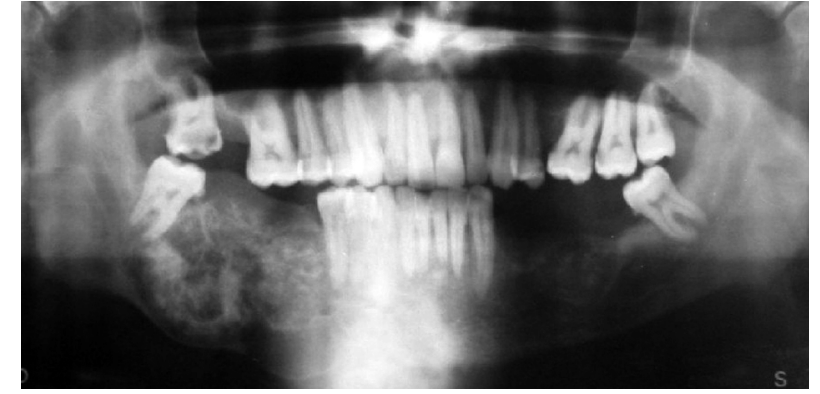

Figura 8. El tumor mandibular del paciente $\mathrm{n}^{\circ} 3$.

Figure 8. The mandibular tumour of patient 3.

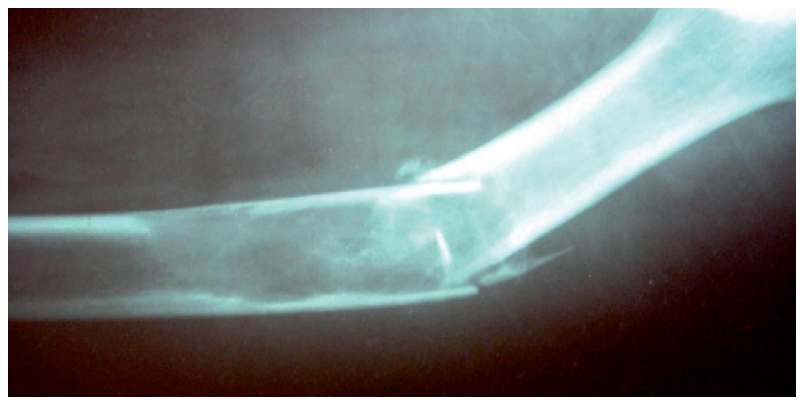

Figura 9. Fractura patológica del fémur en una zona de osteólisis policíclica, que es característica de los tumores pardos del hiper-

Figure 9. Pathologic fracture of the femur, on an area of polycyclic osteolysis, characteristic of the brown tumours of hyperparathyroidism.

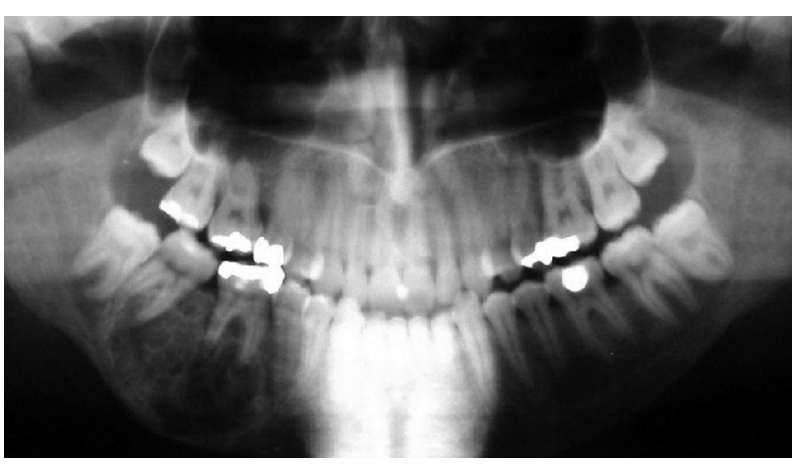

Figura 10. El fibroma osificante del paciente $n^{\circ} 4$. Figure 10. The ossifying fibroma of patient 4.
Since then, his blood calcium and parathormone levels have remained normal, his mandibular tumour has not grown and the patient does not wish to have it removed.

Case 4

This patient, the daughter of patient 2, was evaluated in our department in 1995, at the age of 21 years. She presented with a tumour on the fourth quadrant (Fig. 10) that was well demarcated, extended to the basilar border and looked almost like a cyst, but with slight trabeculation.

Knowing her family history of hyperparathyroidism and jaw tumours, she was referred to the endocrinology department for evaluation.

She was found to have elevated blood calcium and parathormone levels and advanced fibrous cystic osteitis (Fig. 11). Her parathyroid adenoma was removed, followed later by segmental right hemimandibulectomy and reconstruction with a cadaveric allograft (Fig. 12). The tumour was an ossifying fibroma.

\section{Case 5}

This patient, the daughter of patient 3, underwent biochemical and radiological screening when she was 14 years old. She was found to have hypocalcaemia, hyperparathyroidism, two tumours of the jaws (second and fourth quadrants) and several renal cysts.

Lower right parathyroidectomy was performed for a parathyroid adenoma. Blood calcium levels were normal for one year, after which they again started increasing. She underwent surgery again (left upper and lower parathyroidectomy, and removal of half of the right upper parathyroid for an adenoma in the left upper gland).

The jaw lesions kept on growing and several months later she had the two ossifying fibromas removed.

Subsequently, she had another episode of hyperparathyroidism and another operation to remove the ade- 
El hiperparatiroidismo es de origen tumoral, no de hiperplasia paratiroidea, como sucede en los síndromes de neoplasia endocrina múltiple. En el HPTTM, los adenomas a menudo son quísticos; la incidencia de carcinoma es del $5 \%$, mucho más alta que la incidencia de este cáncer en la población general (1:5.000.000). ${ }^{11,14,15}$ No es infrecuente que un paciente desarrolle varios adenomas tras resecar uno, ${ }^{8}$ como sucedió en los pacientes 1 y 5 .

El fibroma osificante está presente en aproximadamente la mitad de los pacientes y su comportamiento es independiente de la calcemia.8,9 Está bien delimitado e inicialmente radiotransparente, pero se calcifica es progresivamente. Puede desplazar o, raramente, destruir las raíces dentarias. En las imágenes radiológicas puede asemejarse a la displasia fibrosa, pero la displasia fibrosa no tiene bordes definidos y no destruye las raíces dentarias. Su aspecto histológico es de hueso en un estroma fibrocelular, con zonas de hueso laminar $y$, a veces, cemento. A diferencia, el hueso laminar y el cemento no aparecen en la displasia fibrosa.

En los pacientes que tienen hiperparatiroidismo, el fibroma osificante puede coexistir con la osteítis fibroquística, que origina lesiones sobre todo radiotransparentes y multifocales, y que tiene un aspecto histológico de fibrosis, hemorragia medular y abundantes células gigantes. Estas lesiones, también conocidas como tumores pardos, tienen un aspecto histológico que es difícil distinguir del aspecto de los tumores y granulomas de células gigantes, el quiste aneurismático de hueso e, incluso, la displasia fibrosa (como ocurrió con el paciente $n^{\circ} 3$ ), aunque son mucho menos numerosas las células gigantes en la displasia fibrosa. El hiperparatiroidismo debe descartarse cuando se encuentran estos hallazgos en una biopsia, especialmente si las lesiones son múltiples.

En este grupo de pacientes emparentados, los tumores maxilares parecían tener una mayor penetrancia que el 50\% habitual, ya que 5 de los 7 pacientes con la anomalía genética tuvieron fibromas maxilares. Estos tumores se presentaron a la edad típica (de 14 a 32 años)

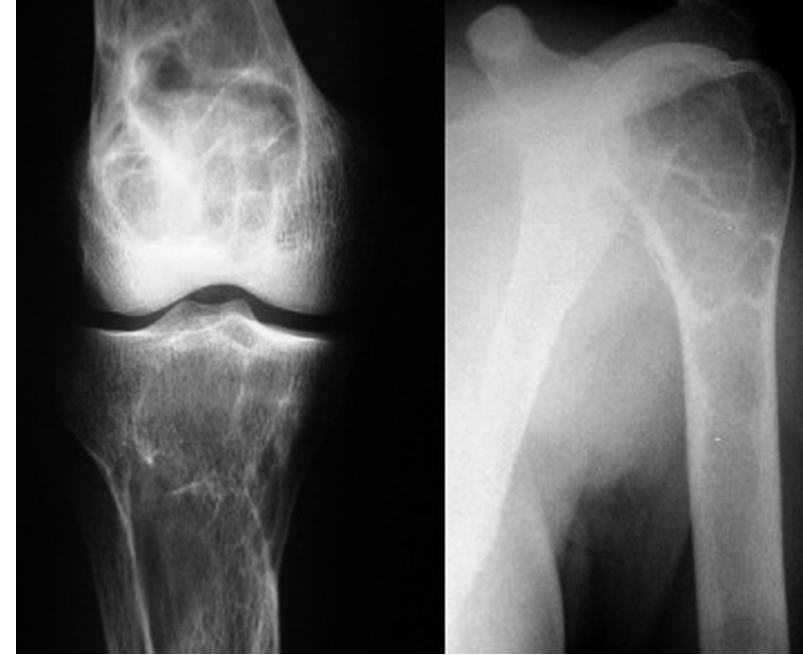

Figura 11. Osteítis fibroquística de la rodilla derecha y hombro izquierdo.

Figure 11. Fibrous cystic osteitis of the right knee and left shoulder.

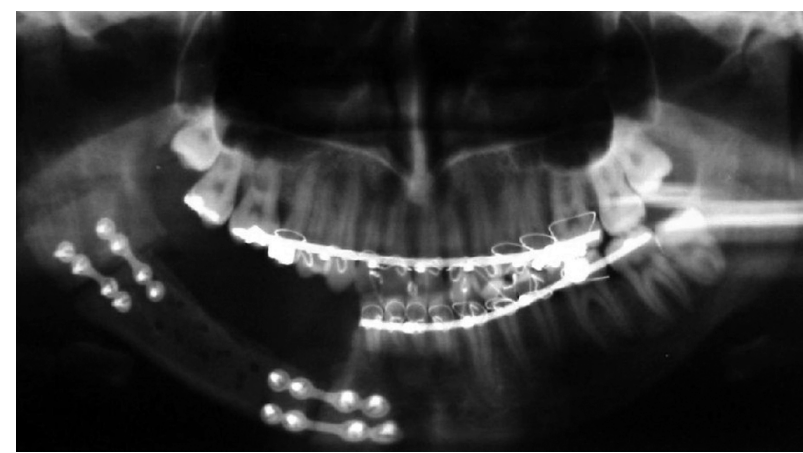

Figura 12. La reconstrucción (estudio radiológico inmediato). Figure 12. The reconstruction (immediate radiological evaluation).

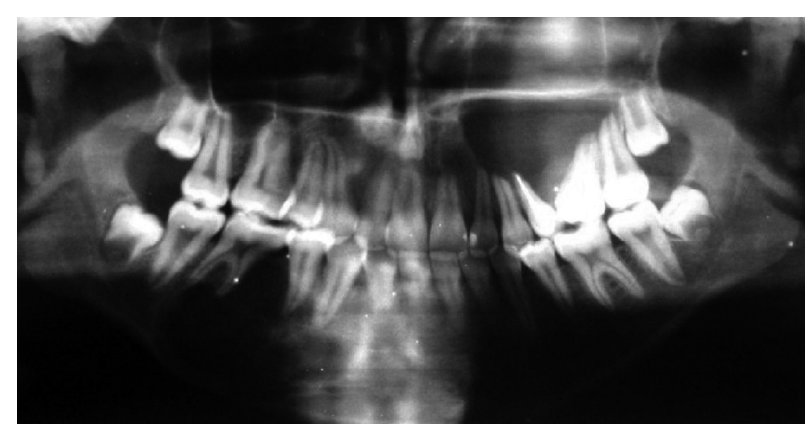

Figura 13. Los tumores del paciente $\mathrm{n}^{\circ} 5$, con una radiotransparencia casi total, desplazan las raíces dentarias.

Figure 13. The tumours on patient 5, almost entirely radiolucent, displacing the dental roots. noma on the remaining gland. There is no sign of relapse or new jaw tumours.

\section{Discussion}

In 1958, Jackson ${ }^{6}$ described a family with hereditary hyperparathyroidism, in most cases also with jaw tumours, after the observations of other authors defined this syndrome; and differentiated it from MEN-1 and MEN-2.8

HPT-JT is an autosomal dominant hereditary disease mapped to chromosome 1 (1q25-q31) ${ }^{9}$ that causes parathyroid tumours, ossifying jaw fibroma, several renal lesions (cysts, Wilms' tumour, hamartoma, cortical adenoma, papillary cell carcinoma), and other tumours (pancreatic adenocarcinoma, testicular tumour, Hürthle cell tumour of the thyroid, adenomyomatous polyps of the uterus). ${ }^{10-12,18}$

The most frequent manifestations (parathyroid adenomas and ossifying fibromas) appear at younger ages than in sporadic cases, which are more frequent in middle age ${ }^{12}$ and after the third decade, ${ }^{13}$ respectively.

Hyperparathyroidism is the result of the tumours, not parathyroid gland hyperplasia, as in MEN syndromes. In HPT-JT, adenomas are frequently cystic and the incidence of carcinoma is 5\%, much higher than the incidence of this cancer in the general population $(1: 5,000,000) \cdot 11,14,15$ It is not uncommon for a patient to develop several adenomas after the extirpation of one, 8 as occurred with patients 1 and 5 .

Ossifying fibromas are present in about half of the patients and their behaviour is independent from blood cal- 
y evidenciaron un comportamiento clínico variable: ninguna recidiva en los pacientes 1,4 y 5 (durante períodos de 58,7 y 3 años), crecimiento muy lento durante más de 30 años en el paciente $n^{\circ} 3$ y crecimiento persistente multifocal en el paciente $n^{\circ} 2$.

El hiperparatiroidismo se manifestó de varias maneras: simulando metástasis óseas (paciente $\mathrm{n}^{\circ} 1$ ), originando nefrolitiasis y fracturas patológicas (paciente $n^{\circ} 3$ ), con silencio clínico y

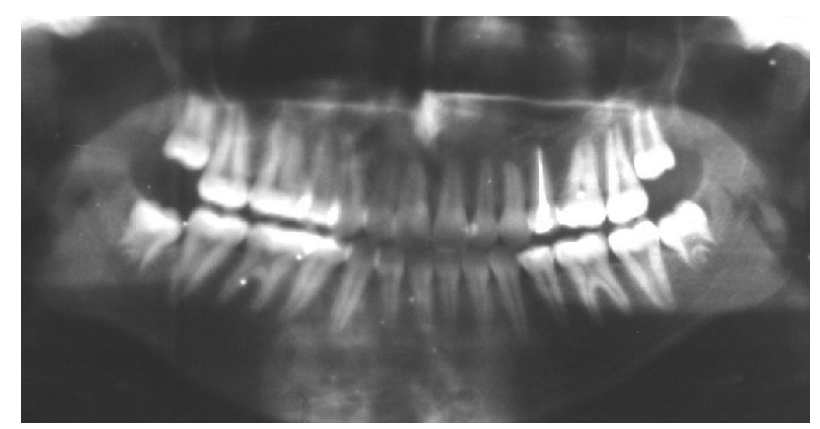

Figura 14. Rectificación espontánea de las raíces dentarias. Figure 14. Spontaneous uprighting of dental roots.

cium levels.8,9 They are well delimited and initially radiolucent, but become progressively calcified. They can displace or, rarely, destroy the dental roots. Radiologically, they might appear similar to fibrous dysplasia, but this disorder has undefined borders and does not destroy the dental roots. Histologically, they are composed of woven bone in a fibrocellular stro$\mathrm{ma}$, with areas of lamellar bone and, sometimes, o unicamente como alteración bioquímica (paciente $\mathrm{n}^{\circ}$ 5). Cada uno de estos pacientes, excepto el $n^{\circ} 1$, era mucho más joven que el paciente habitual con hiperparatiroidismo esporádico.

Ésta es una alteración rara que puede presentarse inicialmente como tumor maxilar. Los especialistas en cirugía oral y maxilofacial deben conocer su existencia con el fin de descartar el hiperparatiroidismo en pacientes que presentan fibroma osificante, como ya hacen muchos cirujanos en los casos de granuloma o un tumor de células gigantes y de displasia fibrosa multifocal.

En los pacientes afectados, se debe tratar el hiperparatiroidismo y explorar los otros órganos, incluido el área maxilofacial, para detectar fibromas osificantes porque estos pueden recurrir, incluso después de normalizarse la calcemia. Se les debe ofrecer a las familias asesoramiento genético.

\section{Bibliografía}

1. Aurbach G, Marx S, Spiegel A. Parathyroid hormone, calcitonin and calciferols. En: Wilson JD, Foster D ed. Textbook of Endocrinology, $7^{\text {a }}$ ed. Filadelfia, WB Saunders 1992:1397-476.

2. Heath $\mathrm{H}$, Hobbs M. Familial hyperparathyroid syndromes. En: Favus MJ, ed. Primer on Metabolic Bone Disorders and Disorders of Mineral Metabolism. $3^{\mathrm{a}} \mathrm{ed}$ Filadelfia, Lippincott-Raven 1996;187-9.

3. Teh BT, Farnebo F, Twigg S, Höög A y cols. Familial isolated hyperparathyroidism maps to the hyperparathyroidism-jaw tumor locus in 1q21-q32 in a subset of families. J Clin Endocrinol Metab 1998;83:2214-20.

4. Cetani F, Pardi E, Giovannetti A, Vignali E y cols. Genetic analysis of the MEN1 gene and HPRT2 locus in two Italian kindreds with familial isolated hyperparathyroidism. Clin Endocrinol 2002;56:457-64.

5. Cavaco BM, Barros L, Pannett AAJ, Ruas $L$ y cols. The hyperparathyroidism-jaw tumour syndrome in a Portuguese kindred. Q J Med 2001;94:213-22.

6. Jackson CE. Hereditary hyperparathyroidism associated with recurrent pancreatitis. Ann Intern Med 1958;49:829-36.

7. Rosen IB, Palmer JÁ. Fibroosseous tumors of the facial skeleton in association with primary hyperparathyroidism: an endocrine syndrome or coincidence? Am I Surg 1981;142:494-8.

8. Jackson CE, Norum RA, Boyd SB, Talpos GB y cols. Hereditary hyperparathyroidism and multiple ossifying jaw fibromas: a clinically and genetically distinct syndrome. Surgery 1990;108:1006-13. cementum. In contrast, lamellar bone and cementum do not develop in fibrous dysplasia.

In patients with hyperparathyroidism, ossifying fibromas might coexist with fibrous cystic osteitis lesions, which are mostly radiolucent and multifocal, and consist histologically of fibrosis, bone marrow haemorrhage and numerous giant cells. These lesions, also known as brown tumours, are hard to distinguish histologically from giant-cell tumours and granulomas, aneurysmal bone cysts and even fibrous dysplasia (as occurred with patient 3), although giant cells are much less numerous in fibrous dysplasia. Hyperparathyroidism should be ruled out when one of the above findings is made in a biopsy, especially if lesions are multiple.

In this kindred, jaw tumours seemed to have a higher penetrance than the usual $50 \%$, as 5 of 7 patients with the abnormal gene had jaw fibromas. These tumours appeared at the typical age (14 to 32 years) and showed variable clinical behaviour: no relapse in patients 1, 4 and 5 (for 58,7 and 3 years), very slow growth for over 30 years in patient 3 , and persistent, multifocal growth in patient 2 .

Hyperparathyroidism manifested itself in several ways: by simulating bone metastases (patient 1), causing nephrolithiasis and pathologic fractures (patient 3), clinically silence with extensive bone lesions (patient 4), or as only a biochemical abnormality (patient 5). In every case except patient 1, patients were much younger than the average patient with sporadic hyperparathyroidism.

This is a rare disorder that can present initially with a jaw tumour. Oral and maxillofacial surgeons should be aware of its existence in order to rule out hyperparathyroidism in patients with ossifying fibroma, as many surgeons already do in cases of giant-cell granulomas and tumours or multiple fibrous dysplasia foci.

In the patients affected, hyperparathyroidism must be treated, and other organs, including the maxillofacial area, must be screened as ossifying fibromas can reappear even after the normalization of blood calcium levels. Families should be offered genetic counselling. 
9. Szabo J, Heath B, Hill V, Jackson C y cols. Hereditary hyperparathyroidism-jaw tumour syndrome: The endocrine tumour gene HRPT2 maps to chromosome 1q21-q31. Am J Hum Genet 1995;56:944-50.

10. Teh BT, Farnebo F, Kristoffersson U, Sundelin B y cols. Autosomal dominant primary hyperparathyroidism and jaw tumour syndrome associated with renal hamartomas and cystic kidney disease: linkage to 1q21-q32 and loss of the wild type allele in renal hamartomas. J Clin Endocrinol Metab 1996;81:4204-11.

11. Dinnen JS, Greenwood RH, Jones JH, Walker DA y cols. Parathyroid carcinoma in familial hyperparathyroidism. / Clin Pathol 1977;30:966-75.
12. Haven CJ, Wong FK, van Dam EW, Van der Juijt y cols. A genotypic and histopathological study of a large Dutch kindred with hyperparathyroidism-jaw tumor syndrome. J Clin Endocrinol Metab 2000;85:1449-54.

13. Eversole LR, Leider AS, Nelson K. Ossifying fibroma: a clinicopathologic study of sixty-four cases. Oral Surg Oral Med Oral Pathol 1985;60:505-11.

14. Streeten EA, Weinstein LS, Norton JA y cols. Studies in a kindred with parathyroid carcinoma. J Clin Endocrinol Metab 1992;75:362-6.

15. Wassif WS, Moniz CF, Friedman E, Wong S y cols. Familial isolated hyperparathyroidism: a distinct genetic entity with an increased risk of parathyroid cancer. J Clin Endocrinol Metab 1993;77:1485-9. 